\title{
Autoradiographic Localization and Biochemical Characteristics of M1 and M2 Muscarinic Binding Sites in the Striatum of the Cat, Monkey, and Human
}

\author{
Mary A. Nastuk and Ann M. Graybiel \\ Department of Brain and Cognitive Science, Whitaker College of Health Science, Technology and Management, \\ Massachusetts Institute of Technology, Cambridge, Massachusetts 02139
}

The autoradiographic distribution of M1 and M2 muscarinic cholinergic binding sites was studied in the striatum of the cat, monkey, and human, and concurrent binding assays were carried out on striatal tissue sections from the cat. M1 sites were directly labeled with ${ }^{3} \mathrm{H}$-pirenzepine; $\mathrm{M} 2$ sites were labeled as a consequence of binding competition between pirenzepine and ${ }^{3} \mathrm{H}-\mathrm{N}$-methylscopolamine. Serial section analysis with autoradiograms and stained tissue sections allowed for comparisons among $\mathrm{M} 1$ and M2 binding distributions and $A C h E$ staining patterns.

The 2 subtypes of binding sites demonstrated distinct striatal distributions. M2 sites were virtually homogeneous except in the ventral striatum, where zones of sparse and especially dense binding were observed. Striatal M1 sites were generally more abundant than M2 sites and showed similar heterogeneity in the ventral striatum. Dorsally, however, patches of dense M1 binding were found, and proved to correspond with AChE-poor striosomes, hallmarks of striatal compartmentalization. The finding of differing distributions for the 2 subtypes of muscarinic cholinergic binding sites suggests a mechanism for the intrinsic spatial segregation of striatal cholinergic function. Further, the striosomal patterning of $M 1$ binding indicates that certain aspects of cholinergic function in the striatum may be constrained and thus regulated by the compartmental ordering characteristic of this region of the basal ganglia.

Subtypes of muscarinic cholinergic binding sites have been defined based upon analysis of binding assays for agonists (Birdsall et al., 1978) and for the nonclassical antagonist pirenzepine (Hammer ct al., 1980). Such assays yield binding curves that most closely approximate curves modeling heterogeneous populations of binding sites. Classes of binding site subtypes showing low, high, or super high affinity for agonists have been termed $\mathrm{L}, \mathrm{H}$, or $\mathrm{SH}$; alternatively, binding sites demonstrating high affinity for pirenzepine (PZ) have been termed M1, while those

\footnotetext{
Received June 16, 1987; revised Sept. 8, 1987; accepted Sept. 10, 1987.
}

We thank Dr. Rudolf Hammer for his gift of pirenzepine, Dr. George R. Ihl for the use of his densitometer, and Mr. Henry F. Hall for his help with the photography. This work was supported by NSF BNS8319547, the Seaver Institute, the McKnight Foundation, and a Whitaker Health Sciences Fund Fellowship (M.A.N.).

Correspondence should be addressed to Mary A. Nastuk, Department of Brain and Cognitive Science, E25-618, Whitaker College of Health Science, Technology and Management, Massachusetts Institute of Technology, Cambridge, MA 02139. Copyright (C) 1988 Society for Neuroscience $0270-6474 / 88 / 031052-11 \$ 02.00 / 0$ having low affinity for pirenzepine are called M2. Further distinctions among muscarinic subtypes have been characterized by their differential binding affinities in the presence of the sulfhydryl reagent $N$-ethylmaleimide (Ehlert et al., 1980; Korn et al., 1983; Flynn and Potter, 1985) or in varying concentrations of divalent cations (Potter et al., 1984) or sodium (Watson et al., 1983). Such effects may reflect variations in the coupling of receptor molecules to associated regulatory proteins, or $\mathrm{G}$ proteins. However, a full understanding of the molecular mechanisms specifying particular subclasses of muscarinic binding sites is not yet in hand. Possibilities include the ability of receptor molecules to interconvert among different affinity states, differences in local membrane environments, and the existence of more than one species of receptor molecule. The latter hypothesis is supportcd by the recent cloning of a muscarinic receptor thought to be the Ml subtype (Kubo et al., 1986). Nonetheless, all of these possibilities probably contribute in some capacity to an explanation of the pharmacological observations indicating the presence of multiple muscarinic binding site subtypes. They are also likely to be involved in specifying among a variety of cellular responses mediated by muscarinic receptors, including breakdown of phosphoinositides (Fisher and Agranoff, 1987), inhibition of adenylate cyclase (Olianas et al., 1983a), and the regulation of certain potassium, sodium, and calcium channels (North, 1986).

The first efforts to localize muscarinic binding sites to specific regions of the mammalian brain involved autoradiography with ligands that did not recognize subtypes, such as ${ }^{3} \mathrm{H}$-quinuclidinyl benzilate $\left({ }^{3} \mathrm{H}-\mathrm{QNB}\right)$ and ${ }^{3} \mathrm{H}$-propylbenzilylcholine mustard $\left({ }^{3} \mathrm{H}\right.$ PrB). These early studies pointed to the striatum as a brain region with a notably dense, uniform level of ${ }^{3} \mathrm{H}-\mathrm{QNB}$ and ${ }^{3} \mathrm{H}-$ PrB binding (Kuhar and Yamamura, 1976; Rotter et al., 1979a; Brand, 1980). It was later possible to show with autoradiograms of varying exposure times that in the cat there were hints of patterning in striatal ${ }^{3} \mathrm{H}-\mathrm{PrB}$ binding, and serial section analysis revealed that patches of particularly dense binding coincided with AChE-poor zones known as striosomes (Nastuk and Graybiel, 1985). Further, vivid patches of ${ }^{3} \mathrm{H}-\mathrm{PrB}$ binding werc sccn in the developing striosomal system of the fetal striatum of several species, including human (Rotter et al., 1979b; Nastuk and Graybiel, 1985). These findings raised the possibility that striatal muscarinic cholinergic function might be spatially parcelled. The fact that the patterning was obscure at maturity, though, suggested that either the heterogeneity was only subtle at adulthood or, as is true for striatal opiate receptors (Moskowitz and Goodman, 1984), a more overt compartmental- 
ization was present but masked due to the simultaneous demonstration of muscarinic binding site subtypes having different distributions.

Autoradiographic and biochemical methods have been developed for studying subclasses of muscarinic binding sites directly with subtype-selective ligands such as ${ }^{3} \mathrm{H}$-pirenzepine and others, and indirectly through competition among multiple ligands (Potter et al., 1984; Wamsley et al., 1984; Yamamura et al., 1985; Giraldo et al., 1987). With methods such as these we have analyzed the distributions of M1 and M2 muscarinic binding sites (see also Nastuk and Graybiel, 1986) in the striatum of the cat, monkey, and human after first confirming that the binding to be studied in this way had a valid biochemical basis. The principal autoradiographic finding is that in all 3 species, striatal M1 sites in the dorsal striatum are especially concentrated in dense patches aligned with striosomes, whereas M2 sites do not demonstrate this type of patchiness. In midventral and ventral regions of the dorsal striatum, zones of sparse binding are evident for both types of muscarinic binding sites. In the ventral striatum, small patches of especially dense $\mathrm{M} 2$ binding are evident. These results suggest that some, but not all, aspects of striatal cholinergic function may be compartmentalized, with such spatial organization reflecting the molecular and functional characteristics of muscarinic receptor subtypes.

\section{Materials and Methods}

Observations were made on striatal tissue from 7 adult cats, 3 adult monkeys (cynomolgus), and 5 adult humans ( 3 male and 2 female, ages 74-84). Human tissue was obtained at autopsy (postmortem delay $4-$ $24 \mathrm{hr}$ ) from individuals with no known history of neurologic disease. At autopsy, blocks from the striatum were quickly dissected out and frozen on crushed dry ice. The blocks were kept at $-70^{\circ} \mathrm{C}$ prior to sectioning as described below for the animal tissue. Tissue from the cats and monkeys was obtained without perfusion under conditions of deep barbiturate anesthesia. Brains were quickly removed, frozen on crushed dry ice, and mounted on cryostat chucks. For biochemical experiments, brains were cut into left and right halves before freezing; once mounted and in the cryostat, blocks were trimmed as close to the edges of the striatum as possible. Coronal sections through the striatum were cut in the cryostat at -12 to $-14^{\circ} \mathrm{C}$. Section thickness was either $15 \mu \mathrm{m}$ (for autoradiography and histochemistry) or $10 \mu \mathrm{m}$ (for binding assays). Sections for binding assays were taken from midrostral levels of the striatum, where rostrocaudal variability in cross-sectional area was minimal. Sections were thaw-mounted onto gelatin-coated slides, to be proccsscd for $\mathrm{M} 1$ or $\mathrm{M} 2$ ligand binding autoradiography, AChE staining by a modified Geneser-Jensen and Blackstad protocol (Geneser-Jensen and Blackstad, 1971), or binding assays. For all procedures involving ligand binding, sections were placed temporarily after thaw-mounting into racks at about $4^{\circ} \mathrm{C}$ and then kept under vacuum at $0^{\circ} \mathrm{C}$ for $2-4 \mathrm{hr}$ in a vacuum desiccator buried in crushed ice and containing Drierite capsules. Slides were then stored at $-20^{\circ} \mathrm{C}$ in sealed boxes containing Drierite for at least 2 weeks before further processing (Lewis et al., 1982).

For ligand binding autoradiography, sections were preincubated in $50 \mathrm{~mm}$ sodium phosphate $\left(\mathrm{NaHPO}_{4}\right)$ buffer at $\mathrm{pH} 7.4$ containing 10 $\mathrm{mm}$ ethylenediaminetetraacetic acid (EDTA) and $0.1 \mathrm{~mm} N$-ethylmaleimide (NEM) for $15 \mathrm{~min}$ at $4^{\circ} \mathrm{C}$ to uncouple binding of endogenous agonist without affecting antagonist binding (Potter et al., 1984). Incubations were then carried out for $1 \mathrm{hr}$ at room temperature in $50 \mathrm{~mm}$ $\mathrm{NaHPO}_{4}$ buffer containing $1 \mathrm{mM}$ EDT $\Lambda$ and either $10 \mathrm{nM}{ }^{3} \mathrm{H}-\mathrm{PZ}(76.0$ $\mathrm{Ci} / \mathrm{mmol}$; New England Nuclear) for M1 binding or $0.3 \mathrm{nM}{ }^{3} \mathrm{H}-\mathrm{N}$-methylscopolamine ( ${ }^{3} \mathrm{H}-\mathrm{NMS} ; 85.0 \mathrm{Ci} / \mathrm{mmol}$; New England Nuclear), and 100 or $200 \mathrm{nM}$ unlabeled PZ (gift of R. Hammer) for M2 binding. These concentrations of $\mathrm{PZ}$ were chosen to occlude as many M1 sites $\left(K_{d} \mathrm{ca}\right.$. $10 \mathrm{~nm}$ ) as possible while leaving most M2 sites ( $K_{d}$ ca. $\left.600 \mathrm{nM}\right)$ free for labeling. For blanks, $1 \mu \mathrm{m}$ atropine was added to the incubation solution. To terminate binding, the sections were immersed for $5 \mathrm{~min}$ in chilled $\left(4^{\circ} \mathrm{C}\right) 50 \mathrm{~mm} \mathrm{NaHPO}{ }_{4}$ buffer containing $1 \mathrm{~mm}$ EDTA. Two very brief rinses in distilled water at $4^{\circ} \mathrm{C}$ followed, and the sections were then dried under a stream of cool air. Slides were apposed to LKB tritium-sensitive

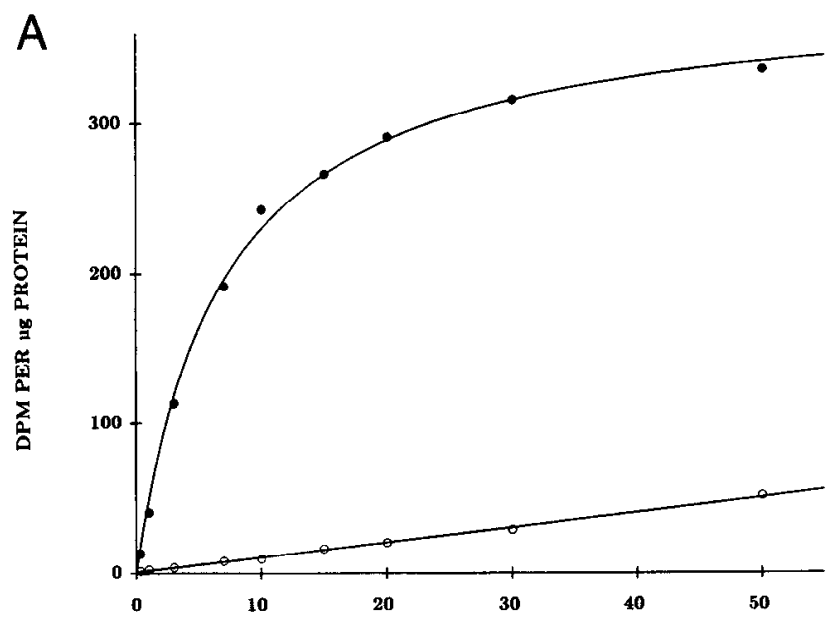

['H-PZ], nM

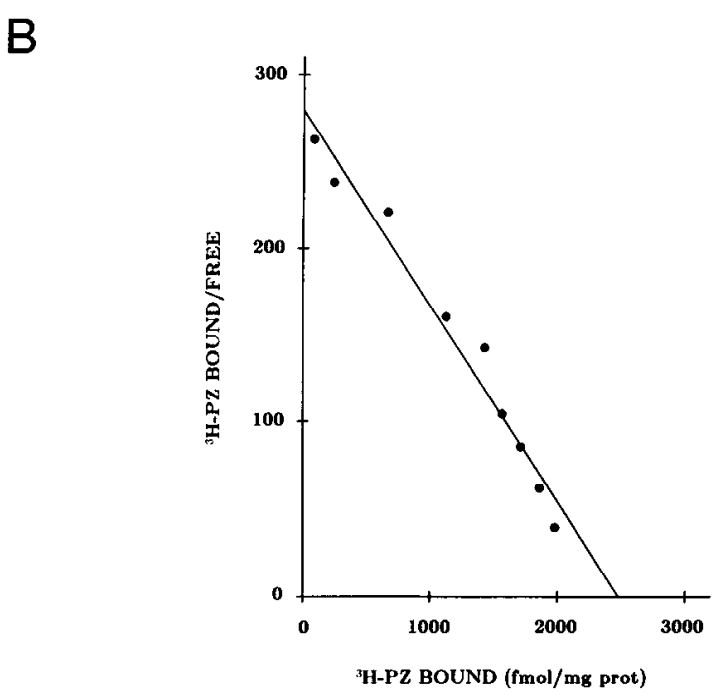

Figure 1. A, Saturation analysis of ${ }^{3} \mathrm{H}-\mathrm{PZ}$ binding to striatal tissue sections from the cat. Specific binding $(\boldsymbol{O})$ is the difference between total binding and nonspecific binding. Nonspecific binding $(O)$ was determined in the presence of $1 \mu \mathrm{M}$ atropine. Each point represents the mean counts from 3 experiments, each carried out in quadruplicate ( 3 animals, 4 sections per animal per point). $B$. Scatchard analysis of the specific binding of ${ }^{3} \mathrm{H}-\mathrm{PZ}$. Linear regression analysis was performed to determine $K_{d}$ and $B_{\max }$.

film for 12-29 d at room temperature. Films were developed in Kodak D19 for 4 min at $20^{\circ} \mathrm{C}$ and then fixed in Kodak Rapid Fixer. Serial section comparisons were made among striatal Ml binding distributions, M2 binding distributions, and AChE staining patterns. Densitometry was performed on M1 autoradiograms of feline and human tissue to estimate the degree of variability in binding density within a given tissue section. For each of 5 sections per case, 5-14 pairs of measurements of grain density were made from visible patch and neighboring nonpatch regions in the dorsal striatum of 1 cat and 1 human. The percentage difference in grain density in and out of patches was averaged for each section; then, an overall mean percentage difference was determined for each case.

For direct binding assays, sections from blocks trimmed down to the striatum as described were preincubated under the same conditions as were sections destined for autoradiography. Groups of 3 or 4 sections were then incubated in various concentrations of ${ }^{3} \mathrm{H}-\mathrm{PZ}$ or ${ }^{3} \mathrm{H}-\mathrm{NMS}$ (under the same conditions as for autoradiography) with and without $1 \mu \mathrm{M}$ atropine. Concentrations of ${ }^{3} \mathrm{H}-\mathrm{PZ}$ ranged from 0.3 to $50 \mathrm{nM}$, and 

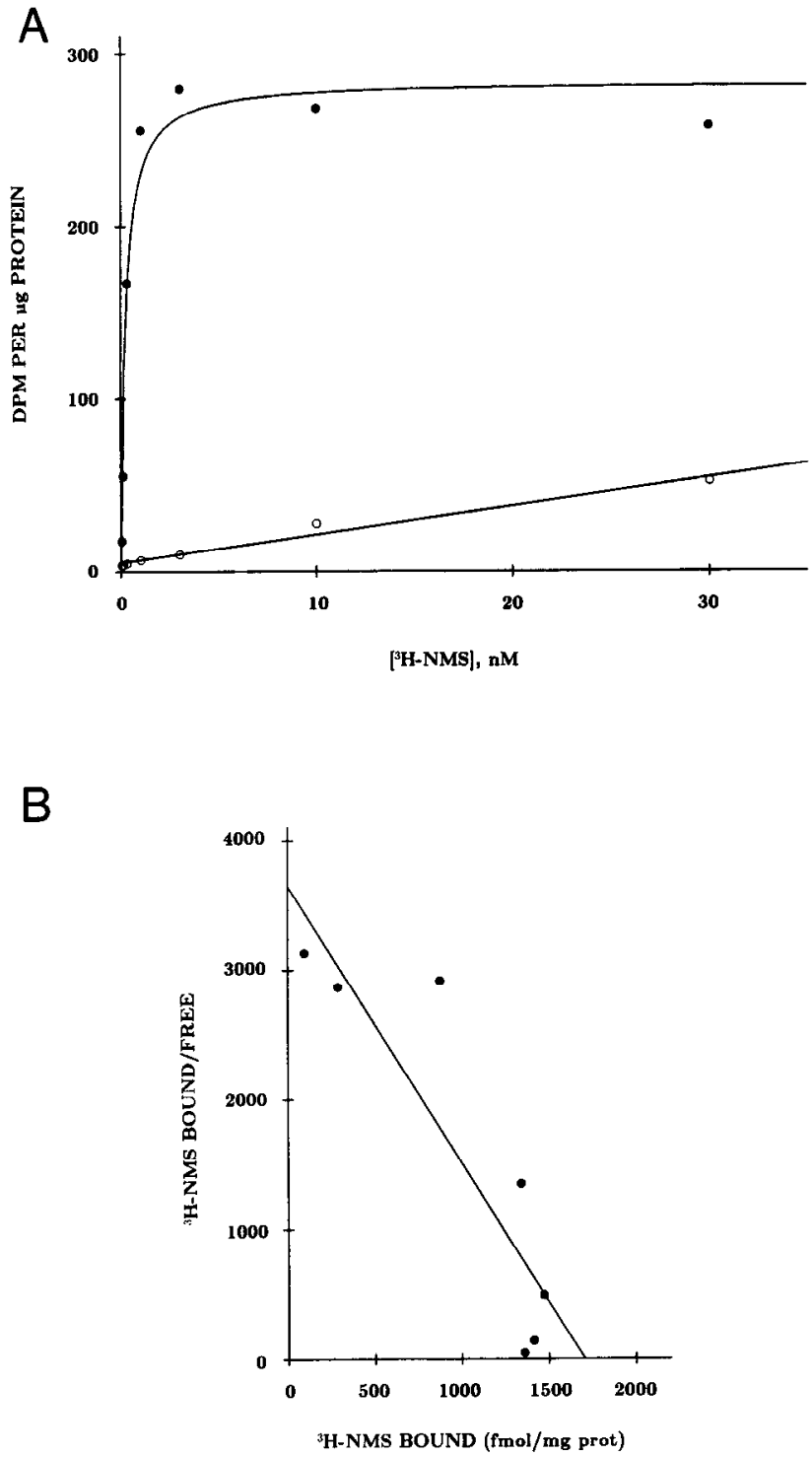

Figure 2. A, Saturation analysis of ${ }^{3} \mathrm{H}-\mathrm{NMS}$ binding to sections from the striatum of the cat. Specific $(\Theta)$ and nonspecific $(O)$ binding were determined in the same way as was done for ${ }^{3} \mathrm{H}-\mathrm{PZ}$. Each point represents mean values for 3 experiments performed in quadruplicate. $B$ Scatchard analysis of the specific binding of ${ }^{3} \mathrm{H}-\mathrm{NMS}$. Linear regression analysis was performed to determine $K_{d}$ and $B_{\max }$.

${ }^{3} \mathrm{H}-\mathrm{NMS}$ concentrations from 0.03 to $30 \mathrm{~nm}$. Following binding termination and rinsing, sections were wiped off slides with Whatman GF/B glass fiber filters or were dried and scraped off, and were placed individually into scintillation vials. Protosol, $1 \mathrm{ml}$ (New England Nuclear), was added to each vial, and the vials were capped and left overnight at $4^{\circ} \mathrm{C}$. A few hours prior to counting in a liquid scintillation counter, $0.1 \mathrm{ml}$ of $30 \%$ hydrogen peroxide (to prevent coloration) was added to each vial, followed by $10 \mathrm{ml}$ of Betafluor (National Diagnostics). Specific and nonspecific binding were calculated from counts, and the Lowry method (1951) was applied to estimate the amount of protein per section. Binding curves were plotted and Scatchard analysis was performed for each of the 2 ligands. Linear regression analysis with the RS1 statistics program was applied both for nonspecific binding curves and Scatchard plots.

For competition experiments, the same procedures were followed as for direct binding assays except that the incubation solutions contained $0.3 \mathrm{~nm}{ }^{3} \mathrm{H}-\mathrm{NMS}$ and concentrations of unlabeled PZ ranging from 0.1 $\mathrm{nM}$ to $10 \mu \mathrm{M}$. Nonspecific binding of ${ }^{3} \mathrm{H}$-NMS was determined in the presence of $1 \mu \mathrm{M}$ atropine. Counts were expressed as percentage occupancy, with $100 \%$ being the specific counts in the absence of any dis-

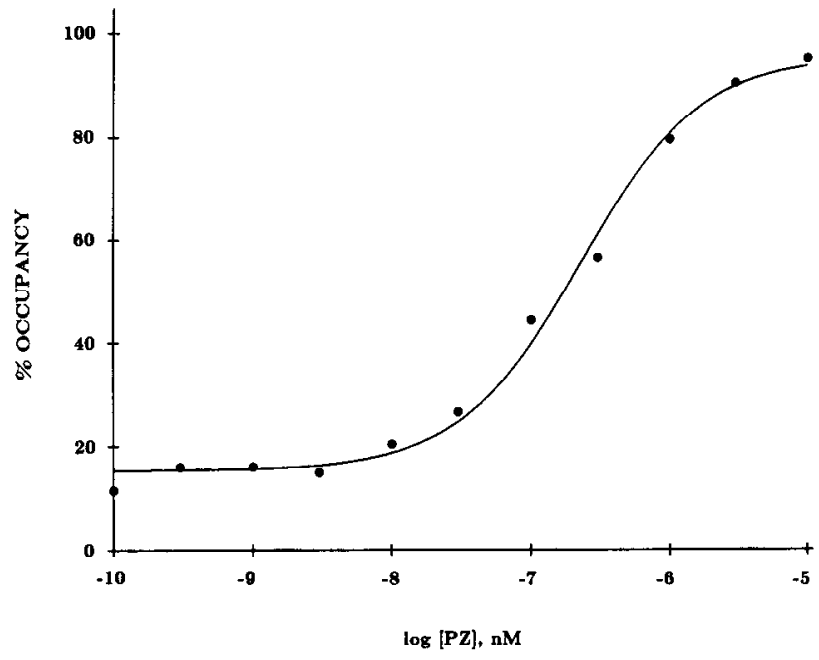

Figure 3. Ability of $\mathrm{PZ}$ to compete with ${ }^{3} \mathrm{H}-\mathrm{NMS}(0.3 \mathrm{nM})$ for binding to striatal tissue sections from the cat. Concentrations of $\mathrm{PZ}$ ranged from $0.1 \mathrm{nM}$ to $10 \mu \mathrm{M}$. Each point represents the mean percentage occupancy in 3 experiments, each conducted in quadruplicate. Specific binding of ${ }^{3} \mathrm{H}-\mathrm{NMS}$ in the absence of displacer was taken as $100 \%$ occupancy. Curve fitting was performed with nonlinear regression analysis.

placer. Points for a competition curve were plotted from the resulting counts, and nonlinear curve fitting was performed with the LIGAND program (Munson and Rodbard, 1980) to determine whether there was a better fit to a 1- or a 2-site model. A Hill plot was also constructed from the occupancy concentration data, and a Hill coefficient was calculated.

\section{Results}

\section{Biochemical studies}

Figure $1 A$ shows a direct binding curve for low concentrations of ${ }^{3} \mathrm{H}-\mathrm{PZ}$ (incubations in very high ligand concentrations were not included here, as the present experiments serve to characterize high-affinity ${ }^{3} \mathrm{H}-\mathrm{PZ}$ binding, i.e., binding to the $\mathrm{M} 1$ site). For this concentration range, ${ }^{3} \mathrm{II}-\mathrm{PZ}$ binding had a saturable specific component and a nonspecific component that increased linearly (correlation coefficient $r=0.99$ ) as ligand concentration was increased. At $10 \mathrm{~nm}{ }^{3} \mathrm{H}-\mathrm{PZ}$, the concentration chosen for subsequent autoradiographic experiments, nonspecific binding comprised less than $0.5 \%$ of total binding. Scatchard analysis (Fig. $1 B$ ) yielded a linear plot $(r=0.97)$ and revealed that, for our experimental conditions, ${ }^{3} \mathrm{H}-\mathrm{PZ}$ bound to a population of striatal sites with a $K_{d}$ of 8.9 .

Specific direct binding of ${ }^{3} \mathrm{H}-\mathrm{NMS}$ to striatal tissue was saturable (Fig. $2 A$ ), and nonspecific binding rose linearly with increasing ligand concentration $(r=0.97)$. Less than $4 \%$ of total binding was nonspecific at an incubation concentration of 0.3 $\mathrm{nM}^{3} \mathrm{H}$-NMS, the concentration used for autoradiography. The plot obtained with Scatchard analysis (Fig. $2 B$ ) demonstrated a linear fit $(r=0.79)$ and indicated that ${ }^{3} \mathrm{H}-\mathrm{NMS}$ binding in the striatum of the cat had a $K_{d}$ of 0.47 . However, it was found that ${ }^{3} \mathrm{H}-\mathrm{NMS}$ adhered relatively readily to the glass walls of the incubation vessel and to the glass slides on which the sections were mounted.

The occupancy concentration curve for the competitive binding of PZ and ${ }^{3} \mathrm{H}-\mathrm{NMS}$ (Fig. 3) shows that under the present experimental conditions, $\mathrm{PZ}$ competes with ${ }^{3} \mathrm{H}-\mathrm{NMS}$ for binding to striatal sites. The data points fit well $(p<0.05)$ to a curve describing 2 populations of $\mathrm{PZ}$ binding sites. High-affinity (M1) 

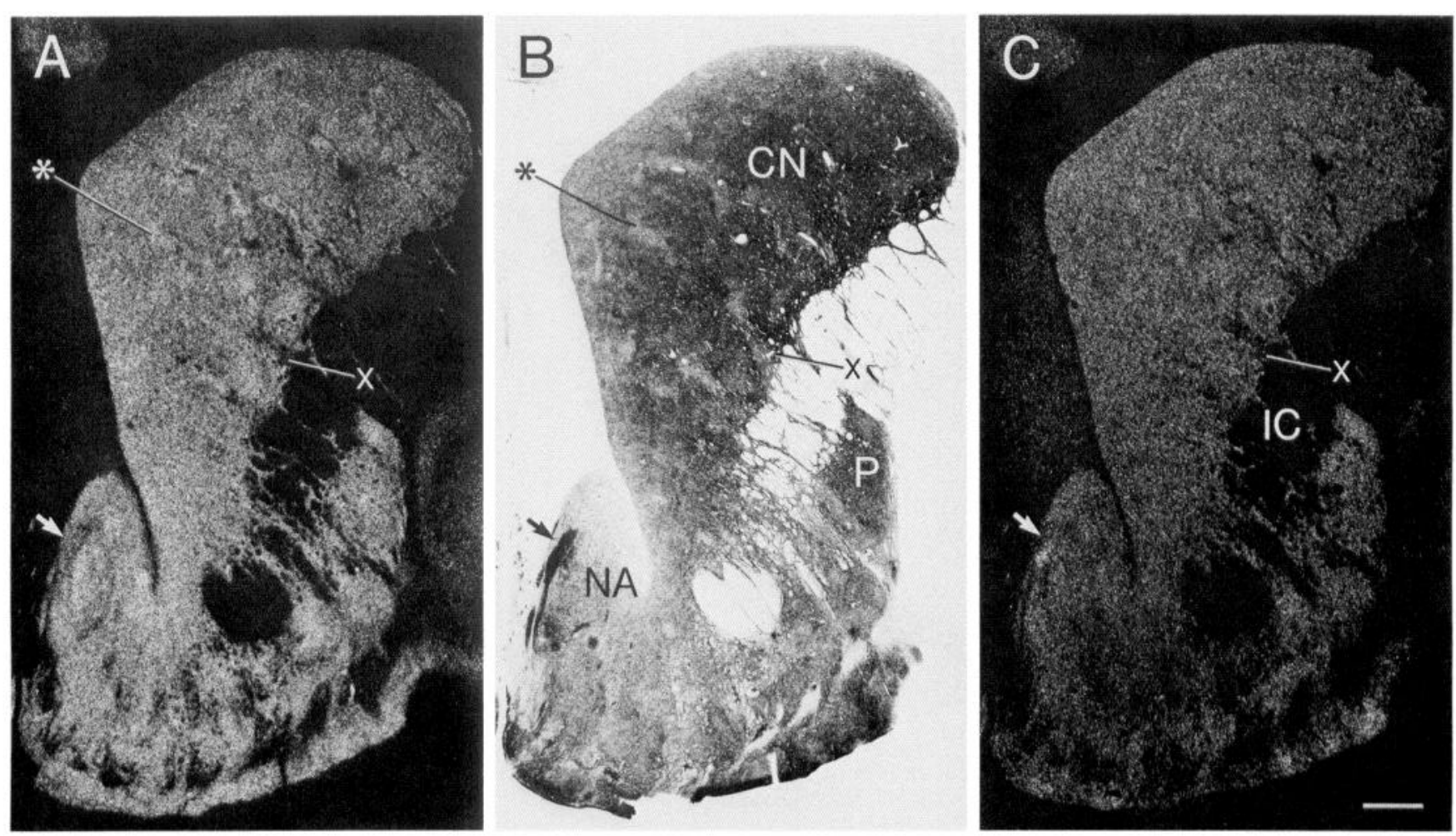

Figure 4. Photographs of consecutive serial coronal sections through the striatum of a cat showing the M1 binding distribution $(A$, dark field), $\mathrm{AChE}$ staining ( $B$, light field), and M2 binding distribution ( $C$, dark field). For dark-field photographs, areas rich in binding sites appear lighter than areas of sparse binding. Zones of particularly dense MI binding in the dorsal striatum correspond to AChE-poor striosomes (asterisks). Farther ventrally, some sparse zones are present in all 3 marker patterns ( $\times$ 's). The insula major of Calleja (arrows), intensely stained with AChE, is weakly labeled with M1 binding and partially labeled with dense M2 binding. $C N$, caudate nucleus; $P$, putamen; $N A$, nucleus accumbens; $I C$, internal capsule. Scale bar, $1 \mathrm{~mm}(A-C$ at same magnification).

sites predominated in number over low-affinity (M2) sites, with a ratio of approximately $14: 1$, as determined from curve fitting to a 2-site model with LIGAND analysis. The Hill coefficient, $n_{\mathrm{H}}$, for the competition data was 0.44 , indicating also the presence of more than one PZ binding site.

\section{Autoradiographic studies}

In all species studied, high-affinity ${ }^{3} \mathrm{H}-\mathrm{PZ}$ binding (M1 binding) to striatal tissue sections was dense but not uniform. Figure $4 A$ shows M1 binding in the cat's striatum, where zones of elevated binding density can be seen. These patches were irregularly shaped with widths of about $0.5-0.8 \mathrm{~mm}$. The patches were most often found middorsally in the striatum (see asterisk in Fig. $4 A$ ); they rarely appeared in the extreme dorsolateral quadrant (the region to the right of the label " $\mathrm{CN}$ " shown in Fig. $4 B$ ), and when found midventrally (in the region at the level of the $\mathrm{X}$ in Fig. $4, A-C$ ), they were not well delineated. Irregularly shaped patches of dense M1 binding also were found in the dorsal striatum of the monkey (Fig. 5A) and human (Fig. 6A), where their widths ranged from about 0.5 to $1.0 \mathrm{~mm}$.

Autoradiograms of tissue sections processed for the binding of ${ }^{3} \mathrm{H}-\mathrm{NMS}$ in the presence of PZ (M2 binding) exhibited few or no densities in the dorsal striatum (Figs. $4 C, 5 C, 6 B$ ). Most sections showed virtually uniform binding that was less dense than the M1 binding (optimal exposure times were nearly twice as long for M2 binding as for M1 binding). For the dorsal striatum, exceptions to this uniformity were found caudally in all 3 species, where occasional patches of very slightly elevated M2 binding were in register with particularly marked M1 patches (results not shown).

Serial-section comparisons between striatal M1 binding distributions and $\mathrm{AChE}$ staining demonstrated that patches of dense binding corresponded to zones of pale AChE staining, or striosomes (Graybiel and Ragsdale, 1978), in the dorsal striatum of the cat (Fig. 4), monkey (Fig. 5), and human (Fig. 7). It was observed in the cat that at certain rostrocaudal levels the M1 patches were more distinct medially, whereas striosomes stood out best laterally (though both macroscopic labeling patterns showed patch-for-patch alignment). Another topographical difference between the 2 marker patterns was that the M1 patches were more crisply delineated caudally than rostrally, but the striosomes seemed equally well demarcated at all levels. This rostrocaudal difference in clarity of M1 patches was noted in all 3 species studied and can be seen in the human tissue on comparing Figures $6 A$ and $7 A$. Figure 7 also reveals that in the dorsal putamen of the human, the M1 binding distribution is more decidedly patterned than is the AChE staining.

To substantiate the visual impression of greater M1 binding in the patches relative to that in the surrounding nonpatch regions, densitometry was performed on autoradiograms of feline and human tissue. For sections from the cat, M1 patches were found to be an average of $20 \%$ denser than their surround; for the human sections, this average percentage difference was $16 \%$. In general the difference in grain density for patches and matrix measured within each section varied; perhaps this was due to mediolateral and dorsoventral differences in patch and matrix 

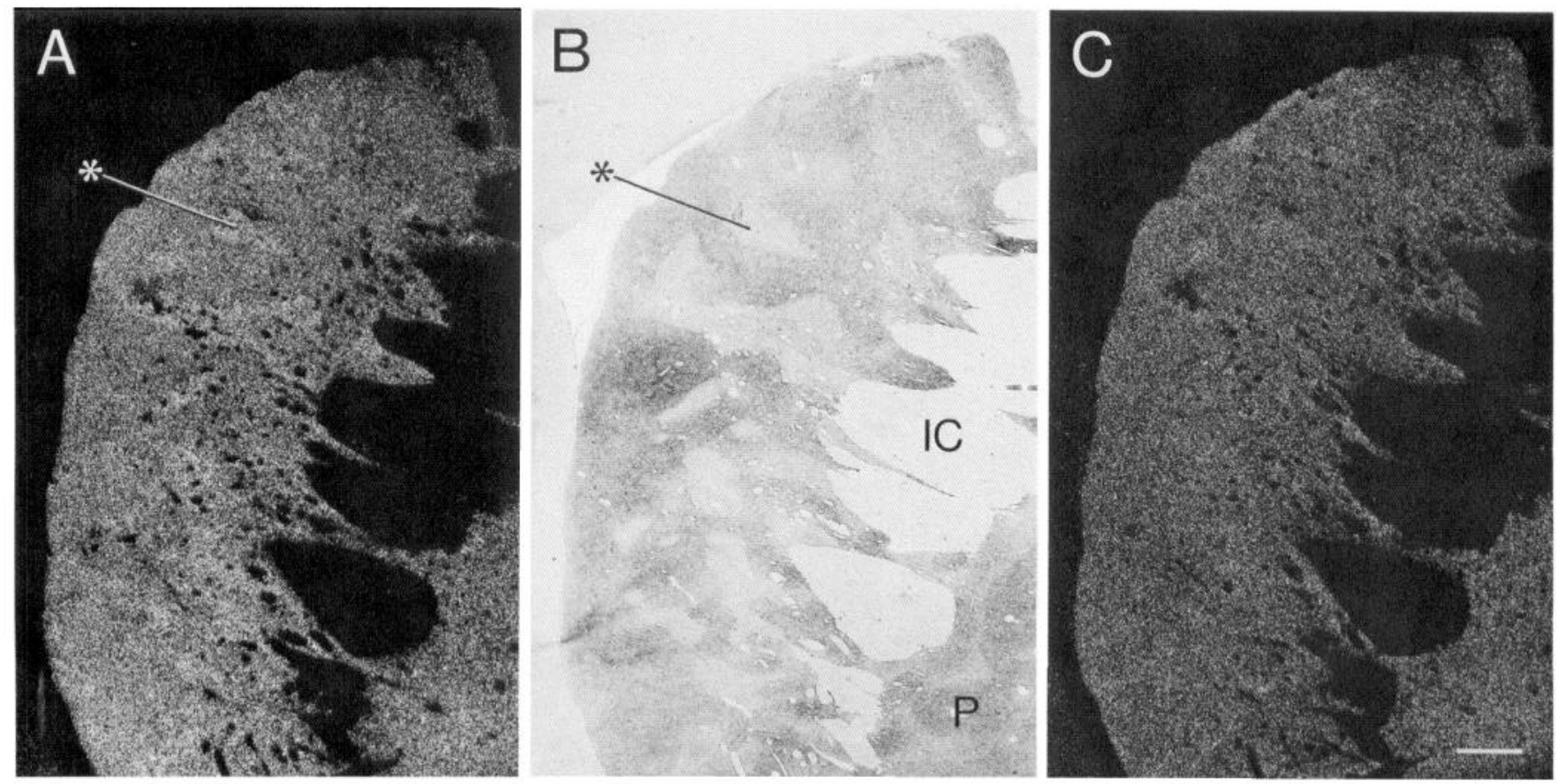

Figure 5. M1 binding ( $A$, dark field), AChE staining ( $B$, light field), and $\mathrm{M} 2$ binding $(C$, dark field) in serially adjacent sections from the striatum of a cynomolgus monkey. Patches densely labeled with M1 binding are in register with striosomes (see asterisks). Such patches are absent in the M2 binding autoradiograph. $P$, putamen; $I C$, internal capsule. Scale bar, $1 \mathrm{~mm}(A-C$ at same magnification).
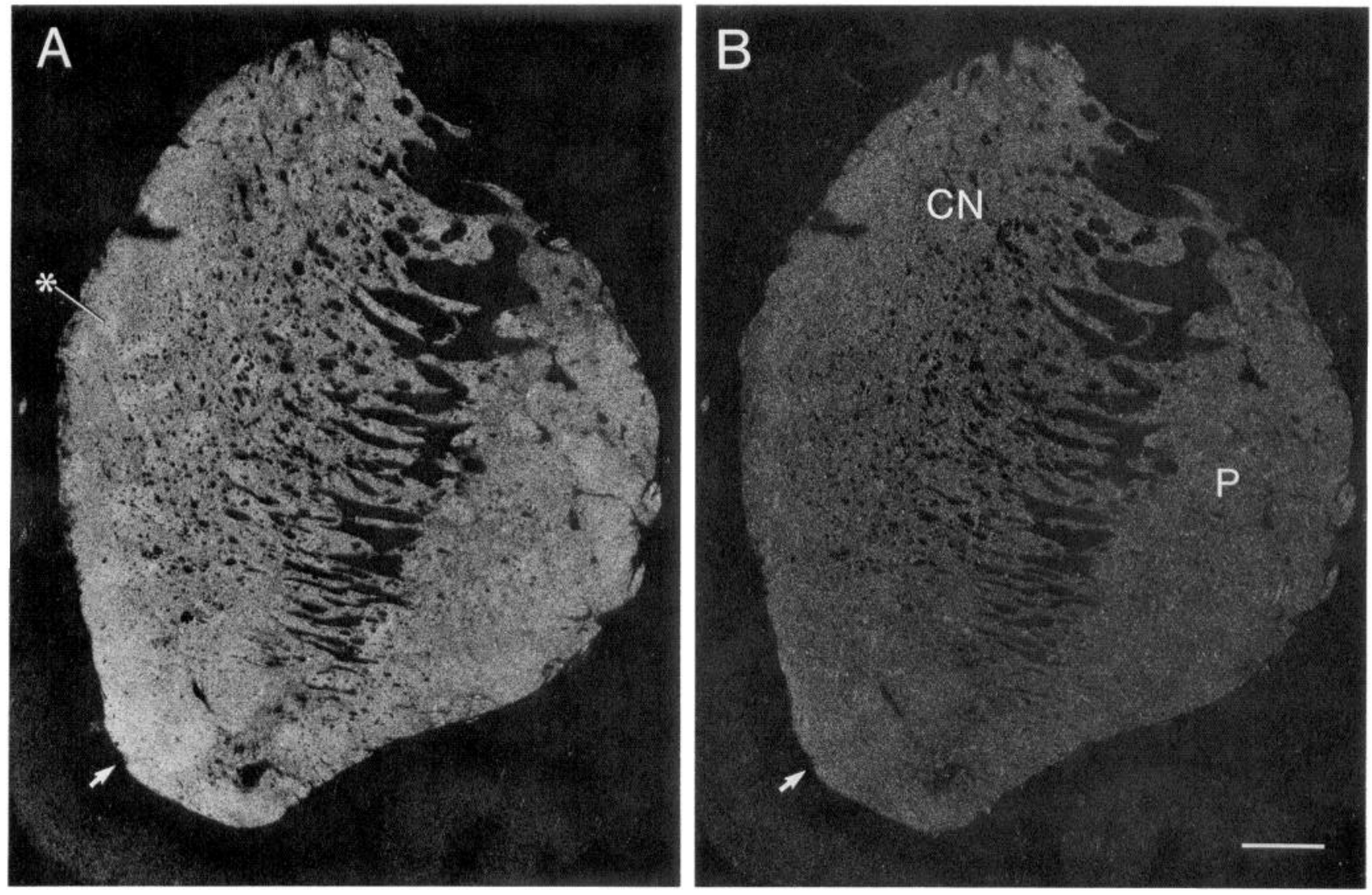

Figure 6. Dark-field photographs of $\mathrm{M} 1(A)$ and $\mathrm{M} 2(B)$ binding in serial sections through the human caudate nucleus and putamen. M1 binding is patchy and generally denser than M2 binding, which lacks discrete patterning. Both types of binding are densest in the region of the ventral striatum (arrows indicate its rostral pole). $C N$, caudate nucleus; $P$, putamen. Scale bar, $3 \mathrm{~mm}$ ( $A$ and $B$ at same magnification). 

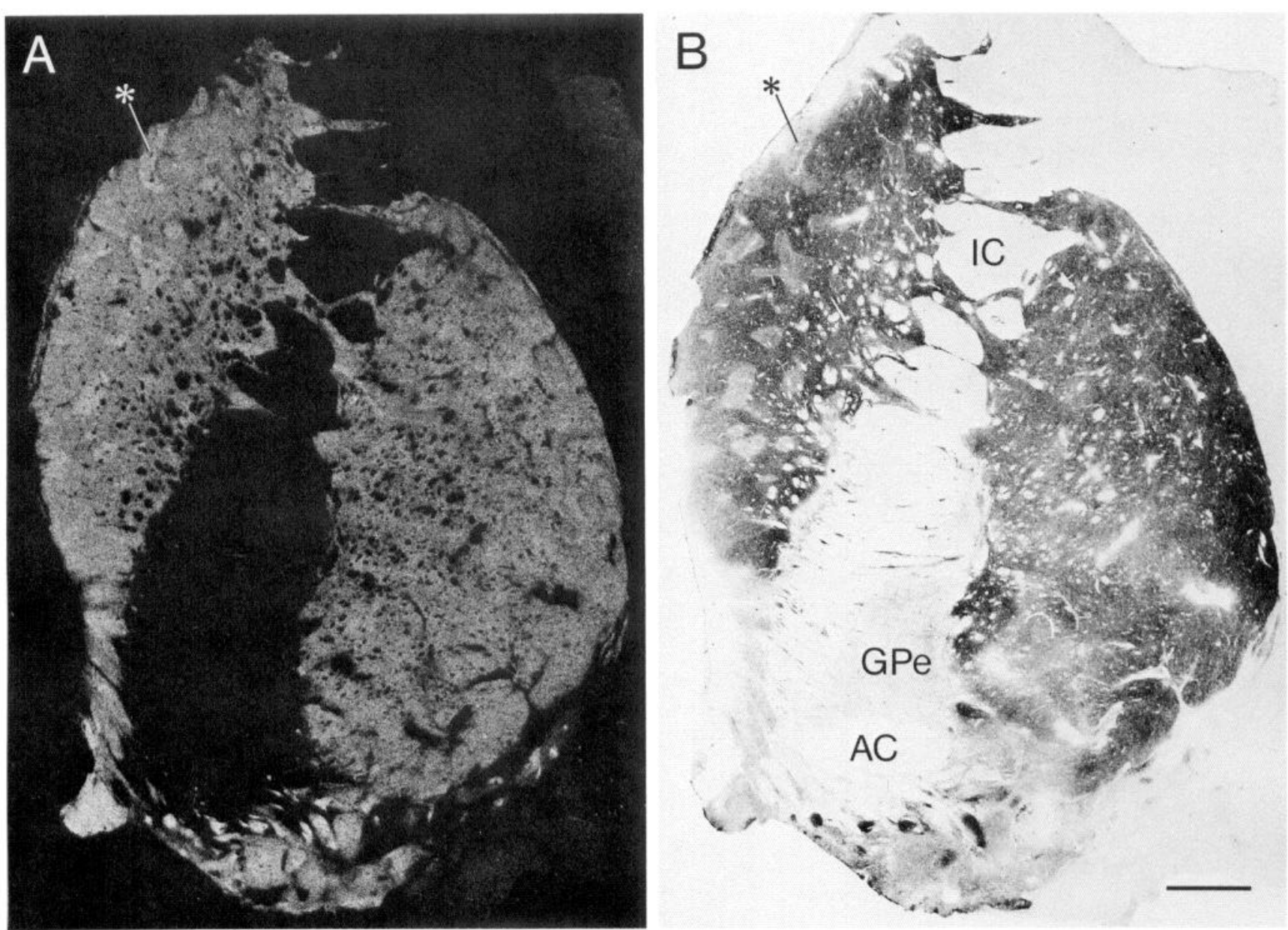

Figure 7. M1 binding ( $A$, dark field) and AChE staining ( $B$, light field) in a serial pair of sections through the human striatum at a level caudal to that shown in Figure 6. Patches of dense M1 binding in the caudate nucleus correspond to striosomes (see asterisks), although in the putamen the pattern of binding does not have a ready counterpart in the enzyme staining. There are virtually no silver grains over the GPe. Note ventrally the punctate zones of dense binding, some of which are matched by AChE-rich patches. $I C$, internal capsule; $A C$, anterior commissure; $G P e$, external segment of globus pallidus. Scale bar, $3 \mathrm{~mm}$ ( $A$ and $B$ at same magnification).

grain density, but a quantitative topographic analysis was not done.

Patterns of autoradiographic labeling in the ventral striatum and nucleus accumbens differed from those found dorsally, both for $\mathrm{M} 1$ and $\mathrm{M} 2$ binding. This ventral region in the cat (Fig. 8, $A, A^{\prime}$ ), monkey (Fig. 8, $B, B^{\prime}$ ) and human (Fig. 9, $A, C$ ) contained not only zones of dense M1 and M2 binding, but also areas of sparse binding for each receptor subtype. The labeling patterns appeared very complicated, especially in the human tissue, with its instances of interdigitation among zones dense and sparse in binding sites. Comparison of the M1 and M2 binding distributions in all species yielded examples of correlations between areas sparse in both types of binding. Such patches were often found ventrally within the putamen (see Fig. 9, $A$ and $C$, for the human, and Figure $8, A$ and $A^{\prime}$, for the cat) and corresponded to AChE-rich zones. But as Figure $8, A$ and $A^{\prime}$, also shows, patches of sparse binding also occurred ventral to the caudate nucleus. In addition, in the olfactory tubercle there were patches dense in both M1 and M2 binding sites (see Figs. 7-9) that were rich in AChE as well. It is unclear whether all of these small patches corresponded to islands of Calleja. Nissl staining of adjacent sections (results not shown) indicated that there was some degree of overlap among patches and islands. The insula major of Calleja was distinct in Nissl stained sections (not shown) and in autoradiograms (see arrows in Fig. 4 and asterisks in Fig. 8) from cat and monkey; it was noteworthy because it contained sparse M1 binding, although a part of it had dense M2 binding.

\section{Discussion}

The primary findings of this study are that tissue sections processed for ligand binding autoradiography show differing macroscopic distributions of striatal M1 and M2 binding sites in the cat, monkey, and human, and that striatal tissue sections from the cat demonstrate valid biochemical characteristics when processed for M1 and M2 muscarinic binding under experimental conditions that were the same as those employed to generate sections for autoradiographic study.

\section{Ligand binding to striatal tissue}

Both ${ }^{3} \mathrm{H}-\mathrm{NMS}$ binding and high-affinity ${ }^{3} \mathrm{H}-\mathrm{PZ}$ binding exhibited saturable specific and linear nonspecific components. Levels of nonspecific binding for each radioligand were extremely low, a phenomenon substantiated by the near invisibility of autoradiographic film images for sections incubated in the presence of atropine. The $K_{d}$ values obtained here for ${ }^{3} \mathrm{H}-\mathrm{NMS}$ binding and high-affinity ${ }^{3} \mathrm{H}$-PZ binding in the cat's striatum agreed with 

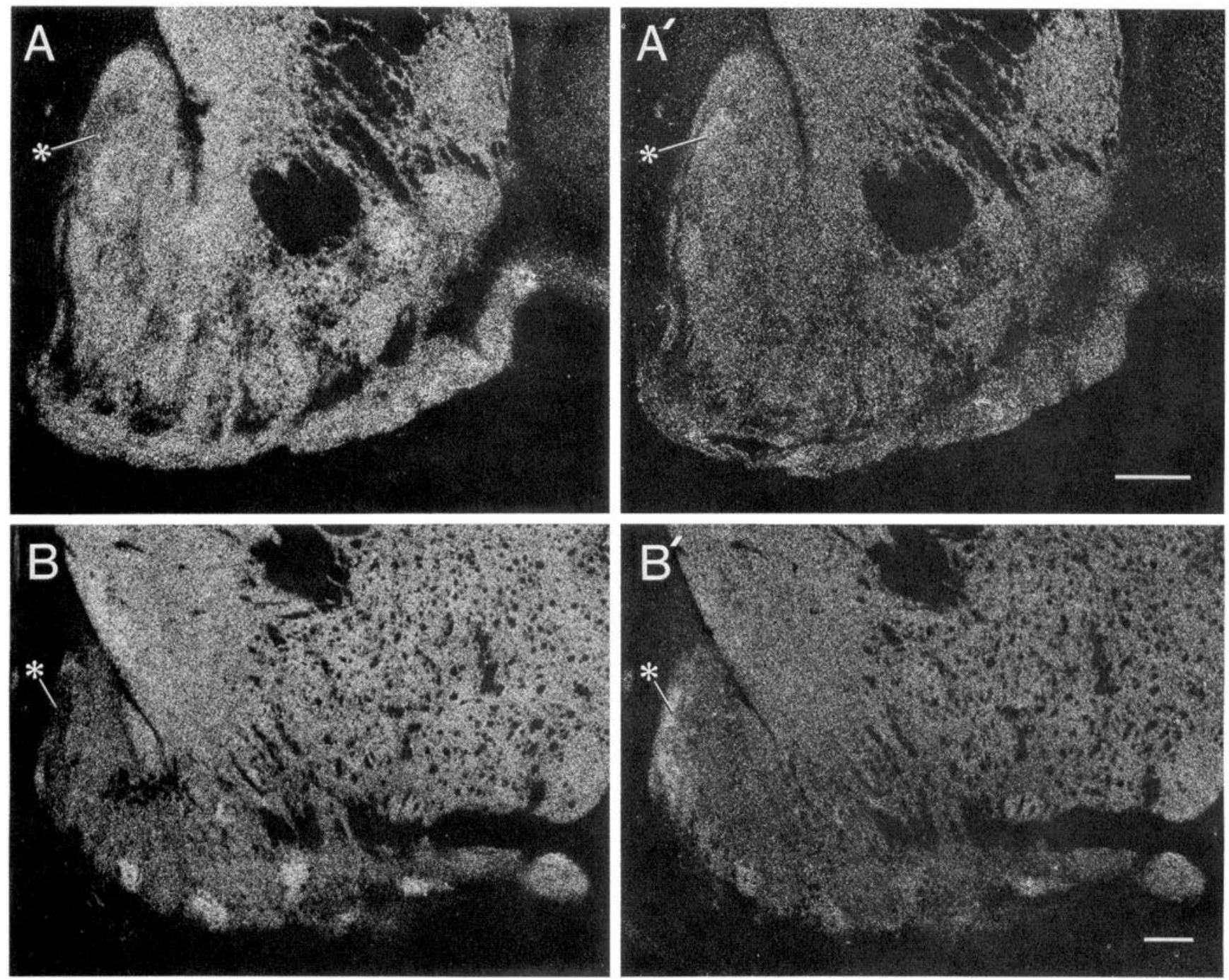

Figure 8. Dark-field photographs showing muscarinic ligand binding in the ventral striatum of the cat $\left(A, A^{\prime}\right)$ and cynomolgus monkey $\left(B, B^{\prime}\right)$. Serial pairs of sections are shown for each species; M1 binding is depicted in $A$ and $B$, and M2 binding is shown in $A^{\prime}$ and $B^{\prime}$. Inhomogeneities are present for both M1 and M2 binding. Islands of Calleja are prominently labeled in the monkey for both M1 and M2 binding. The insula major of Calleja (see asterisks) in both species is notable because it is particularly sparse in M1 binding, though a zone within it contains very dense M2 binding. Scale bar, $1 \mathrm{~mm}\left(A, A^{\prime}\right)$ and $1 \mathrm{~mm}\left(B, B^{\prime}\right)$

values reported by several groups for the binding of these ligands to brain tissue from other mammalian species (Birdsall et al., 1976; Hulme et al., 1978; Hammer et al., 1980; Hammer and Giachetti, 1982; Watson et al., 1983; Yamamura et al., 1983; Luthin and Wolfe, 1985). The $B_{\max }$ for nonselective ${ }^{3} \mathrm{H}-\mathrm{NMS}$ binding to striatal tissue was not greater than that for highaffinity ${ }^{3} \mathrm{H}-\mathrm{PZ}$ binding. Cortes et al. (1986), who reported a similar discrepancy for $B_{\max }$ values, suggested that the problem may arise from an underestimation of the $K_{d}$ for high-affinity ${ }^{3} \mathrm{H}-\mathrm{PZ}$ binding. However, another possible explanation may reside in our finding that ${ }^{3} \mathrm{H}-\mathrm{NMS}$ sticks to glass fairly readily. Thus, values for total bound ${ }^{3} \mathrm{H}$-NMS could be erroneously low when tissue samples, which contain relatively small amounts of the ligand, are placed in glass scintillation vials for counting.

The competition between $\mathrm{PZ}$ and ${ }^{3} \mathrm{H}-\mathrm{NMS}$ for binding to striatal muscarinic sites in the cat yielded a curve that was best fit to a 2-site model in which M1 sites were much more abundant than M2 sites. The autoradiography supported this in that longer exposure times were necessary to obtain appreciable striatal M2 labeling than were required for M1 labeling. However, the autoradiographic findings also demonstrate especially concentrated M2 sites in certain regions of the ventral striatum. This indicates that, although $\mathrm{M} 1$ binding sites are generally viewed as predominating in the striatum (and certainly they do in the dorsal striatum in our material), striatal M2 sites are also likely to be of importance and, in particular, may be of unique importance in the ventral striatum. This may be of relevance in the case of clinical syndromes such as Alzheimer's disease that include degenerative changes in the basal forebrain.

Our autoradiographic analysis shows that for a range of mammalian species, subtypes of striatal muscarinic cholinergic binding sites have different anatomical distributions. Local concentrations of M1 binding correspond to the striosomal compartments inherent to the dorsal striatum, whereas the distribution of M2 binding sites is nearly uniform except in the olfactory tubercle and nucleus accumbens. Even in the ventral 
striatum where both subtypes have heterogeneous distributions, their density profiles are not fully matched, and in some sections appear inverse.

\section{Functional meaning of different striatal $M 1$ and $M 2$ binding distributions}

The present findings may prove critical for understanding the spectrum of cholinergic function in the striatum. First, the spatial distributions of muscarinic binding sites, where heterogeneous, are aligned with the compartmental arrangement characterizing almost all known connections and neurotransmitter-related markers in the striatum, including other cholinergic markers. Second, because the receptors thought to be represented by the M1 and M2 binding are likely to have distinct cellular functions and to be located on different cellular elements, the nature of cholinergic receptor function in the striosomal and matrix compartments may differ. This means that, depending upon their location in striosomes or matrix, certain striatal pathways and neurotransmitter systems could be affected in unique ways by M1 and M2 muscarinic stimulation or inhibition.

It is reasonable to ask whether all the binding sites that are made visible in an autoradiographic study would be functional under physiological conditions. To obtain direct evidence linking the observed macroscopic heterogeneity of striatal muscarinic binding sites with true functional heterogeneity is not yet possible given the presently available experimental approaches. However, a wide variety of cellular effects has been ascribed to muscarinic receptor activation in the striatum, including changes in the spontaneous and evoked release of $\mathrm{ACh}$ and dopamine (see Chesselet, 1984), inhibition of adenylate cyclase (Olianas et al., 1983a), and enhancement of phosphatidylinositol turnover (see Fisher and Agranoff, 1987). Subtype-selective muscarinic stimulation results in discrete electrophysiological effects that have not yet been characterized in striatal tissue but that include both inhibition (M2) and slow excitation (M1) of cortical pyramidal cells (McCormick and Prince, 1985), as well as hyperpolarization of cells in the parabrachial nucleus (Egan and North, 1986) and the reticular nucleus of the thalamus (McCormick and Prince, 1986) with a resultant increase in membrane potassium conductance. Further analysis of muscarinic receptor function in the striatum should take into account the distinctions in anatomical distribution of M1 and M2 binding sites.

\section{Muscarinic binding sites in relation to cholinergic neurons and neuropil}

Markers for the striatal cholinergic system other than muscarinic binding sites also exhibit macroscopic heterogeneity. AChE staining, choline acetyltransferase (ChAT)-positive cells (Graybiel et al., 1983) and neuropil (Graybiel et al., 1987a), and choline uptake sites (Lowenstein et al., 1986) are all distributed more densely in the extrastriosomal matrix than in striosomes. These distributions are in direct contrast to that of M1 binding sites (which show the reverse compartmentalization), and differ also from the largely uniform M2 binding site distribution.

These discrepancies suggest that although cholinergic cell bodies and processes are concentrated outside striosomes, either cholinoceptive cell bodies and processes are more concentrated in striosomes than in matrix or the striosomal cholinoceptive elements maintain greater densities of muscarinic receptors than do cholinoceptive elements found in the matrix. For the subset
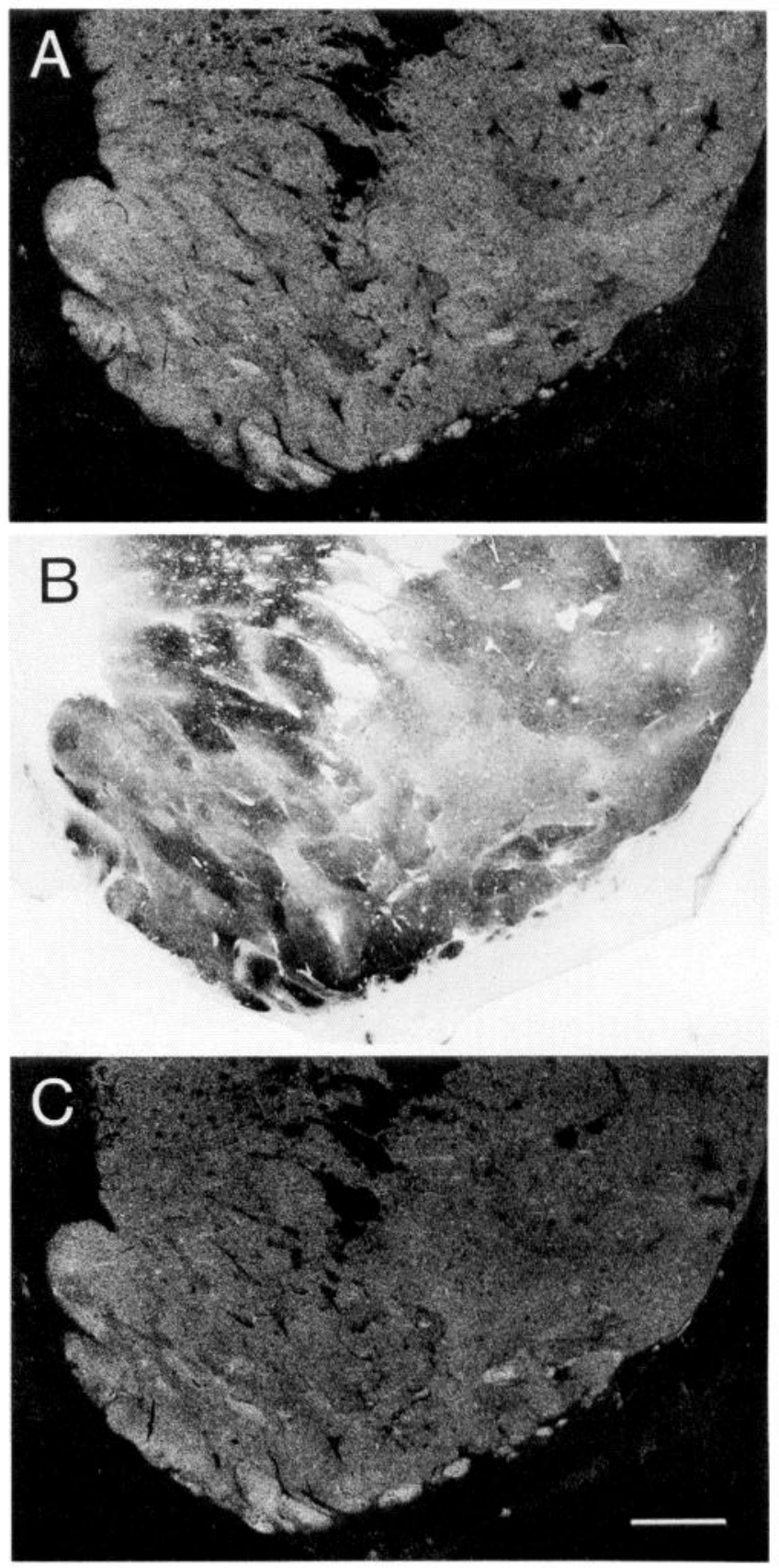

Figure 9. Comparison of $\mathrm{M} 1$ binding ( $A$, dark field), AChE staining $(B$, light field), and $\mathrm{M} 2$ binding ( $C$, dark field) in serial sections through the ventral striatum of the human. All 3 labeling patterns are intricate, showing instances of heavily and lightly labeled patches that are not always in complete register. Patches of dense M2 binding stand out particularly well against a surround of sparser binding. Scale bar, $3 \mathrm{~mm}$ ( $A-C$ at same magnification).

of muscarinic receptors termed autoreceptors, the second explanation is more likely to hold since such receptors would be found on cholinergic neurons themselves, and ChAT-like immunoreactivity is sparse in striosomes (although it cannot be discounted that cholinergic processes within striosomes merely may express lower levels of ChAT than do those in the matrix). Pharmacological evidence obtained from ACh-release studies (James and Cubeddu, 1987) indicates that striatal muscarinic autoreceptors in the rabbit may be of the M2 subtype, though 
M2 receptors may well subserve other functions in this tissue, and there may also be more than one kind of $\mathrm{M} 2$ receptor in the brain (Hammer et al., 1986). It will be necessary to accumulate more evidence of the type that has been found in the cortex (Raiteri et al., 1984; Mash et al., 1985; Meyer and Otero, $1985)$ to show whether some or all striatal M2 receptors are presynaptic. The present autoradiographic results cannot distinguish autoreceptors from among the entire pool of striatal muscarinic receptors (which may include spare receptors lacking function); but it is an interesting possibility nonetheless that differing distributions of autoreceptors in striosomes and matrix could provide for differential and perhaps compartmentalized self-regulation of $\mathrm{ACh}$ release across the striatum. More generally it may be the case that greater numbers of muscarinic receptors are required within striosomes, where, judging from ChAT immunoreactivity, less ACh seems to be available. Higher densities of receptors there could serve as a form of local amplification of cholinergic transmission.

\section{Muscarinic binding and the nigrostriatal dopamine-containing innervation}

Several studies have shown that muscarinic agonists can facilitate the release of dopamine from nigrostriatal terminals, presumably through presynaptic action (see Chesselet, 1984). It has been suggested also that cholinergic augmentation of striatal dopamine release may be mediated by the M1 muscarinic receptor (Raiteri et al., 1984; deBelleroche and Gardiner, 1985). If so, then striosomes may represent sites where such an effect preferentially occurs. Quite another level of interaction between the 2 systems has been proposed with the suggestion that dopamine itself can regulate the affinity of striatal muscarinic receptors (Ehlert et al., 1981). Interactions such as this between the 2 neurotransmitter systems may be governed, at least in part, by the compartmentalization of striatal muscarinic receptors. In addition, many lines of evidence indicate that the nigrostriatal dopaminergic system also obeys striosomal ordering. Tyrosine hydroxylase-like immunoreactivity is more concentrated in the extrastriosomal matrix than in striosomes in both human (Graybiel et al., 1987b) and cat (Newman-Gage and Graybiel, in press). In the rat, fibers labeled by ${ }^{3} \mathrm{H}$-dopamine uptake are concentrated in patches (Doucet et al., 1986), and islandic dopamine-containing fibers may have lower rates of dopamine turnover than do fibers in the matrix (Olson et al., 1972). Such compartmentalization may be related to differences in the sites of origin of mesostriatal fibers innervating striosomes and matrix (Jiminez-Castellanos and Graybiel, 1985, 1986, 1987). There is now also evidence that striatal dopaminergic binding sites are ordered striosomally. Dopaminergic binding sites of the D2 type are distributed more densely in the extrastriosomal matrix (Joyce et al., 1986; Loopuijt et al., 1987), whereas D1 binding sites are more concentrated in striosomes (Besson et al., 1988). The above findings, taken together with the present observations, suggest that a functional parallel exists at a macroscopic level between the striatal dopamine and $\mathrm{ACh}$ systems: for both, neurotransmitter availability, as well as action, may differ with location in striosomes or matrix.

At a molecular level, striatal dopamine and $\mathrm{ACh}$ receptors may be linked through mutual coupling of certain receptor subtypes to adenylate cyclase. There is evidence that in the striatum of the rat, enhancement of adenylate cyclase activity by dopamine can be inhibited by muscarinic receptor stimulation, and coupling of both neurotransmitter receptors to the same domain of adenylate cyclase has been proposed as a mechanism for this interaction (Olianas et al., 1983b). It is thought that the D1 subtype of dopamine receptor is involved in this phenomenon (Kelly and Nahorski, 1986). A possible subtype for the muscarinic receptor in question has not yet been identified. Based on studies of the pharmacology of $\mathrm{PZ}$ in the rat brain, however, it has been suggested that low-affinity PZ binding sites may mediate muscarinic inhibition of adenylate cyclase activity. By contrast, high-affinity $\mathrm{PZ}$ binding sites may be responsible for muscarinic enhancement of the breakdown of phosphatidylinositol, another important second-messenger system (Gil and Wolfe, 1985). Although it is generally far from clear that, for all tissue, the same muscarinic receptor subtype is necessarily always linked to the same second-messenger system (Harden et al., 1986), differential effector coupling of $\mathrm{M} 1$ and $\mathrm{M} 2$ receptors in the striatum would provide for topographically distinct actions of $\mathrm{ACh}$ there. If such a spatial distinction among striatal muscarinic receptors exists at the level of second-messenger systems, then it might provide for the compartmentalization of at least some sequelae of cholinergic receptor activation, including changes in intracellular calcium levels and alterations in neurotransmitter release.

\section{Compartmentalization of cholinergic function in the striatum}

Modulation of neurotransmitter release and receptor affinity, as well as direct or indirect action on ion channels and secondmessenger systems, could be expected to lead to changes in the electrical activity of single neurons or collective groups of neurons. If striatal $\mathrm{M} 1$ and $\mathrm{M} 2$ receptors involved in such effects act and are acted upon in distinct ways, then their differing anatomical distributions might provide a substrate for transstriatal sorting of information flow as it is represented by local perturbations in electrical activity. Such alterations, if present, would likely be subtle because the striatum is well known to be electrically quiescent; but in the face of such quiescence, even small changes in electrical activity could be expected to assume greater relative importance as signaling mechanisms. The inhomogeneities in the density of muscarinic binding site subtypes, as well as of other binding sites found in the striatum (Herkenham and Pert, 1981; Goedert et al., 1984; Moskowitz and Goodman, 1984; Faull and Villiger, 1986; Joyce et al., 1986; Besson et al., 1988), raise the possibility that variations in physiological activity are both spatially and temporally ordered within the striatum, perhaps with respect to its striosomal compartmentalization.

The present findings indicate that compartmentalization may critically effect receptor-mediated function of the striatal cholinergic system at levels ranging from molecular to macroscopic. At the molecular level, muscarinic receptors serve as part of the linkage between the binding of $\mathrm{ACh}$ and subsequent local membrane effects mediated by various ion channels. At the cellular level, muscarinic receptors mediate events such as changes in levels of cytosolic calcium and in the dynamics of neurotransmitter release. Macroscopically, by virtue of their distributions, at least some muscarinic receptors are in a position to exert different molecular and cellular effects on groups of neurons depending upon the locations of these cells relative to striosomes. Muscarinic receptor activation occurring in striosomes may have profoundly different effects on neuronal communication from that occurring extrastriosomally or at the borders separating striatal compartments. 


\section{References}

Besson, M.-J., A. M. Graybiel, and M. A. Nastuk (1988) [ $\left.{ }^{3} \mathrm{H}\right]-\mathrm{SCH} 23390$ binding to D1 dopamine receptors in the basal ganglia of the cat and primate: Delineation of striosomal compartments and pallidal and nigral subdivisions. Neuroscience (in press).

Birdsall, N. J. M., A. S. V. Burgen, C. R. Hiley, and E. C. Iulme (1976) Binding of agonists and antagonists to muscarinic receptors. J. Supramol. Struct. 4: 367-371.

Birdsall, N. J. M., A. S. V. Burgen, and E. C. Hulme (1978) The binding of agonists to brain muscarinic receptors. Mol. Pharmacol. 14: 723-736.

Brand, S. (1980) A comparison of the distribution of acetylcholinesterase and muscarinic cholinergic receptors in the feline striatum. Neurosci. Lett. 17: 113-117.

Chesselet, M.-F. (1984) Presynaptic regulation of neurotransmitter release in the brain: Facts and hypothesis. Neuroscience 12:347-375.

Cortes, R., A. Probst, H.-J. Tobler, and J. M. Palacios (1986) Muscarinic cholinergic receptor subtypes in the human brain. II. Quantitative autoradiographic studies. Brain Res. 362: 239-253.

deBelleroche, J., and I. M. Gardiner (1985) Muscarinic reccptors discriminated by pirenzepine are involved in the regulation of neurotransmitter release in rat nucleus accumbens. Br. J. Pharmacol. 86: 505-508.

Doucet, G., L. Descarries, and S. Garcia (1986) Quantification of the dopamine innervation in adult rat neostriatum. Neuroscience 19: $427-445$.

Egan, T. M., and R. A. North (1986) Acetylcholine hyperpolarizes central neurones by acting on an M2 muscarinic receptor. Nature 319 : 405-407.

Ehlert, F. J., W. R. Roeske, and H. I. Yamamura (1980) Regulation of muscarinic receptor binding by guanine nucleotides and N-ethylmaleimide. J. Supramol. Struct. 14: 149-162.

Ehlert, F. J., W. R. Roeske, and H. I. Yamamura (1981) Striatal muscarinic receptors: Regulation by dopaminergic agonists. Life Sci. 28: $2441-2448$.

Faull, R. L. M., and J. W. Villiger (1986) Heterogeneous distribution of benzodiazepine receptors in the human striatum: A quantitative autoradiographic study comparing the pattern of receptor labelling with the distribution of acetylcholinesterase staining. Brain Res. 381: 153-158.

Fisher, S. K., and B. W. Agranoff (1987) Receptor activation and inositol lipid hydrolysis in neural tissues. J. Neurochem. 48: 9991017.

Flynn, D. D., and L. T. Potter (1985) Different effects of N-ethylmaleimide on M1 and M2 muscarine receptors in rat brain: Proc. Natl. Acad. Sci. USA 82: 580-583.

Geneser-Jensen, F. A., and J. W. Blackstad (1971) Distribution of acetylcholinesterase in the hippocampal region of the guinea pig. I. Entorhinal area, parasubiculum, and presubiculum. Z. Zellforsch. Mikrosk. Anat. 114: 460-481.

Gil, D. W., and B. B. Wolfe (1985) Pirenzepine distinguishes between muscarinic receptor-mediated phosphoinositide breakdown and inhibition of adenylate cyclase. J. Pharmacol. Exp. Ther. 232: 608-616.

Giraldo, E., R. Hammer, and H. Ladinsky (1987) Distribution of muscarinic receptor subtypes in rat brain as determined in binding studies with AF-DX 116 and pirenzepine. Life Sci. 40: 833-840.

Goedert, M., P. W. Mantyh, P. C. Emson, and S. P. Hunt (1984) Inverse relationship between neurotensin receptors and neurotensinlike immunoreactivity in cat striatum. Nature $307: 543-546$.

Graybiel, A. M., and C. W. Ragsdale (1978) Histochemically distinct compartments in the striatum of human, monkey and cat demonstrated by acetylthiocholinesterase staining. Proc. Natl. Acad. Sci. USA 75: 5723-5727.

Graybiel, A. M., M.-F. Chesselet, J. Y. Wu, F. Eckenstein, and T. E. Joh (1983) The relation of striosomes in the caudate nucleus of the cat to the organization of early-developing dopaminergic fibers, GADpositive neuropil, and CAT-positive neurons. Soc. Neurosci. Abstr. 9: 14.

Graybiel, A. M., R. W. Baughman, and F. Eckenstein (1987a) Cholinergic neuropil of the striatum observes striosomal boundaries. Nature 323: 625-628.

Graybiel, A. M., E. C. Hirsch, and Y. A. Agid (1987b) Differences in tyrosine hydroxylase-like immunoreactivity characterize the mesostriatal innervation of striosomes and extrastriosomal matrix at maturity. Proc. Natl. Acad. Sci. USA 84: 303-307.
Hammer, R., and A. Giachetti (1982) Muscarinic receptor subtypes: $\mathrm{M} 1$ and $\mathrm{M} 2$ biochemical and functional characterization. Life Sci. 31: 2991-2998.

Hammer, R., C. P. Berrie, N. J. M. Birdsall, A. S. V. Burgen, and E. C. Hulme (1980) Pirenzepine distinguishes between different subclasses of muscarinic receptors. Nature 283: 90-92.

Hammcr, R., E. Giraldo, G. B. Schiavi, E. Monferini, and H. Ladinsky (1986) Binding profile of a novel cardioselective muscarinic receptor antagonist, AF-DX 116, to membranes of peripheral tissues and brain in the rat. Life Sci. 38: 1653-1662.

Harden, T. K., L. I. Tanner, M. W. Martin, N. Nakahata, A. R. Hughes, J. R. Hepler, T. Evans, S. B. Masters, and J. H. Brown (1986) Characteristics of two biochemical responses to stimulation of muscarinic cholinergic receptors. Trends Pharmacol. Sci. Suppl. 2: 14-18.

Herkenham, M., and C. B. Pert (1981) Mosaic distribution of opiate receptors, parafascicular projections and acetylcholinesterase in rat striatum. Nature 291: 415-418.

Hulme, E. C., N. J. M. Birdsall, A. S. V. Burgen, and P. Mehta (1978) The binding of antagonists to brain muscarinic receptors. Mol. Pharmacol. 14: 737-750.

Jamcs, M. K., and L. X. Cubeddu (1987) Pharmacologic characterization and functional role of muscarinic autoreceptors in the rabbit striatum. J. Pharmacol. Exp. Ther. 240: 203-215.

Jiminez-Castellanos, J., and A. M. Graybiel (1985) The dopaminecontaining innervation of striosomes: Nigral subsystems and their striatal correspondents. Soc. Neurosci. Abstr. 11: 1249.

Jimincz-Castellanos, J., and A. M. Graybiel (1986) Innervation of striosomes and extrastriosomal matrix by different subdivisions of the midbrain A8-A9-A10 dopamine-containing cell complex. Soc. Neurosci. Abstr. 12: 1327.

Jiminez-Castellanos, J., and A. M. Graybiel (1987) Subdivisions of the dopamine-containing A8-A9-A10 complex identified by their differential mesostriatal innervation of striosomes and extrastriosomal matrix. Neuroscience 23: 223-242.

Joyce, J. N., D. W. Sapp, and J. F. Marshall (1986) Human striatal dopamine receptors are organized in compartments. Proc. Natl. Acad. Sci. USA 83: 8002-8006.

Kelly, E., and S. R. Nahorski (1986) Specific inhibition of dopamine D-1-mediated cyclic AMP formation by dopamine D-2, muscarinic cholinergic, and opiate receptor stimulation in rat striatal slices. $\mathrm{J}$. Neurochem. 47: 1512-1516.

Korn, S. J., M. W. Martin, and T. K. Harden (1983) N-Ethylmaleimide-induced alteration in the interaction of agonists with muscarinic cholinergic receptors of rat brain. J. Pharmacol. Exp. Ther. 224: 118126.

Kubo, T., K. Fukuda, A. Mikami, A. Maeda, H. Takahashi, M. Mishina, T. Haga, K. Haga, A. Ichiyama, K. Kangawa, M. Kojima, H. Matsuo, T. Hirose, and S. Numa (1986) Cloning, sequencing and expression of complementary DNA encoding the muscarinic acetylcholine receptor. Nature 323: 411-416.

Kuhar, M. J., and H. I. Yamamura (1976) Localization of cholinergic muscarinic receptors in the rat brain by light microscopic radioautography. Brain Res. 110:229-243.

Lewis, M. E., H. Khachaturian, and S. J. Watson (1982) Visualization of opiate receptors and opioid peptides in sequential brain sections. Life Sci. 31: 1347-1350.

Loopuijt, L. D., J. B. Sebens, and J. Korf (1987) A mosaic-like distribution of dopamine receptors in the rat neostriatum and its relationship to striosomes. Brain Res. 405: 405-408.

Lowenstein, P. R., P. A. Slesinger, H. S. Singer, L. C. Walker, M. F. Casanova, D. L. Price, and J. T. Coyle (1986) Development of cholinergic and dopaminergic pre- and postsynaptic markers in the baboon and human striatum. Soc. Neurosci. Abstr. 16: 1230.

Lowry, O. H., N. J. Rosebrough, A. L. Farr, and R. J. Randall (1951) Protein measurement with the Folin phenol reagent. J. Biol. Chem. 193: $265-275$.

Luthin, G. R., and B. B. Wolfe (1985) Characterization of $\left[{ }^{3} \mathrm{H}\right]$ pirenzepine binding to muscarinic cholinergic receptors solubilized from rat brain. J. Pharmacol. Exp. Ther. 234: 37-44.

Mash, D. C., D. D. Flynn, and L. T. Potter (1985) Loss of M2 muscarine receptors in the cerebral cortex in Alzheimer's disease and experimental cholinergic denervation. Science 228: 115-117.

McCormick, D. A., and D. A. Prince (1985) Two types of muscarinic response to acetylcholine in mammalian cortical neurons. Proc. Natl. Acad. Sci. USA 82: 6344-6348.

McCormick, D. A., and D. A. Prince (1986) Acetylcholine induces 
burst firing in thalamic reticular neurones by activating a potassium conductance. Nature 319: 402-405.

Meyer, E. M., and D. H. Otero (1985) Pharmacological and ionic characterizations of the muscarinic receptors modulating $\left[{ }^{3} \mathrm{H}\right]$ acetylcholine release from rat cortical synaptosomes. J. Neurosci. 5: 1202-1207.

Moskowitz, A. S., and R. R. Goodman (1984) Light microscopic autoradiographic localization of $\mu$ and $\delta$ opioid binding sites in the mouse central nervous system. J. Neurosci. 4: 1331-1342.

Munson, P. J., and D. Rodbard (1980) LIGAND: A versatile computerized approach for characterization of ligand-binding systems. Anal. Biochem. 107: 220-239.

Nastuk, M. A., and A. M. Graybiel (1985) Patterns of muscarinic cholinergic binding in the striatum and their relation to dopamine islands and striosomes. J. Comp. Neurol. 237: 176-194.

Nastuk, M. A., and A. M. Graybiel (1986) Autoradiography of M1 and $\mathrm{M} 2$ muscarinic binding in the striatum. Trends Pharmacol. Sci. Suppl. 2: 92-93.

Newman-Gage, H., and A. M. Graybiel (in press) Expression of calcium calmodulin-dependent protein kinase in relation to dopamine blends and synaptic maturation in the cat striatum. Neuroscience.

North, R. A. (1986) Muscarinic receptors and membrane ion conductances. Trends Pharmacol. Sci. Suppl. 2: 19-22.

Olianas, M. C., P. Onali, N. H. Neff, and E. Costa (1983a) Adenylate cyclase activity of synaptic membranes from rat striatum. Inhibition by muscarinic receptor agonists. Mol. Pharmacol. 23: 393-398.

Olianas, M. C., P. Onali, N. H. Neff, and E. Costa (1983b) Muscarinic receptors modulate dopamine-activated adenylate cyclase of rat striatum. J. Neurochem. 41: 1364-1369.

Olson, L., A. Seiger, and K. Fuxe (1972) Heterogeneity of striatal and limbic dopamine innervation: Highly fluorescent islands in developing and adult rats. Brain Res. 44: 283-288.
Potter, L. T., D. D. Flynn, H. E. Hanchett, D. L. Kalinoski, J. LuberNarod, and D. C. Mash (1984) Independent M1 and M2 receptors: Ligands, autoradiography and functions. Trends Pharmacol. Sci. Suppl. 1: 22-31.

Raiteri, M., R. Leardi, and M. Marchi (1984) Heterogeneity of presynaptic muscarinic receptors regulating neurotransmitter release in the rat brain. J. Pharmacol. Exp. Ther. 228: 209-214.

Rotter, A., N. J. M. Birdsall, A. S. V. Burgen, P. M. Field, E. C. Hulme, and G. Raisman (1979a) Muscarinic receptors in the central nervous sytem of the rat. I. Technique for autoradiographic localization of the binding of $\left[{ }^{3} \mathrm{H}\right]$ propylbenzilylcholine mustard and its distribution in the forebrain. Brain Res. Rev. 1: 141-165.

Rotter, A., P. M. Field, and G. Raisman (1979b) Muscarinic receptors in the central nervous system of the rat. III. Postnatal development of binding of $\left[{ }^{3} \mathrm{H}\right]$ propylbenzilylcholine mustard. Brain Res. Rev. I: 185-205.

Wamsley, J. K., D. R. Gehlert, W. R. Roeske, and H. I. Yamamura (1984) Muscarinic antagonist binding site heterogeneity as evidenced by autoradiography after direct labeling with $\left[{ }^{3} \mathrm{H}\right]-\mathrm{QNB}$ and $\left[{ }^{3} \mathrm{H}\right]-$ pirenzepine. Life Sci. 34: 1395-1402.

Watson, M., H. I. Yamamura, and W. R. Roeske (1983) A unique regulatory profile and regional distribution of $\left[{ }^{3} \mathrm{H}\right]$ pirenzepine binding in the rat provide evidence for distinct $\mathrm{M} 1$ and $\mathrm{M} 2$ muscarinic receptor subtypes. Life Sci. 32: 3001-3011.

Yamamura, H. I., J. K. Wamsley, P. Deshmukh, and W. R. Roeske (1983) Differential light microscopic autoradiographic localization of muscarinic cholinergic receptors in the brainstem and spinal cord of the rat using [ $\left.{ }^{3} \mathrm{H}\right]$ pirenzepine. Eur. J. Pharmacol. 91: 147-149.

Yamamura, H. I., T. W. Vickroy, D. R. Gehlert, J. K. Wamsley, and W. R. Roeske (1985) Autoradiographic localization of muscarinic agonist binding sites in the rat central nervous system with (+)-cis$\left[{ }^{3} \mathrm{H}\right]$ methyldioxolane. Brain Res. 325: 340-344. 